\title{
中学生の学校ストレス過程における因果関係の検討
}

\author{
$\bigcirc$ 命婦 恭子 $^{1} \cdot$ 工藤 晋平 $^{2} \cdot$ 岩田 昇 $^{3}$ \\ ( ${ }^{1}$ 名古屋女子大学・ ${ }^{2}$ 京都大学・ ${ }^{3}$ 広島国際大学) \\ キーワード: 学校ストレス, 中学生, 因果関係
}

\section{Examination of Causal relation in School stress process of Japanese Junior High School Students \\ Yasuko MEIFU $^{1}$, Shimpei KUDO ${ }^{2}$ and Noboru IWATA ${ }^{3}$ \\ ( ${ }^{1}$ Nagoya Women's University , ${ }^{2}$ Kyoto University, ${ }^{3}$ Hiroshima International University) \\ Key Words: school stress junior high school students causal relation}

\section{目 的}

本研究では, 中学生の学校ストレスの実態を明らかにする ために, 一般の公立中学校を対象に, 年 5 回の調査を 3 年間 に渡って実施した。ここでは，中 1 ギャップと表現される入 学後から 1 年間の学校適応について検討を行いたい。発表者 らのこれまでの研究では, 年度当初のストレッサー, ストレ ス反応の高低による群わけを行うと, それぞれの群の特徴を 1 年間は維持しており, ストレス反応が高い群は, その後も 他の群よりストレス反応が高く, レジリエンスやソーシャ ル・サポートが低いということが明らかなになった（命婦ら， 2010)。ここでは，この結果を踏まえ，1年生の年度当初状況 による 1 年間の学校ストレスの差異についての分析を行う。

また， 1 年生の学校ストレッサーとストレス反応の因果関 係の検討を行う。さらに，ライフスタイルとの因果関係につ いても分析を行い, 中学校入学というライフイベントを経験 している生徒たちへ, どのような側面から援助介入を行うこ とが有効か考察することを目的としている。

\section{方 法}

\section{1. 対象}

広島県内の A 公立中学校に 2008 年から 2010 年に在籍した 生徒。本研究では，そのうち毎年の 1 年生 677 人を分析対象 とした。0 08 年 233 人 $(\mathrm{M}: 127, \mathrm{~F}: 106), 09$ 年 252 人 (M: $123, \mathrm{~F}: 129)$, 10 年 192 人 $(\mathrm{M}: 94, \mathrm{~F}: 98)$ 。

\section{2. 尺度}

1）パブリックヘルスリサーチセンター版ストレスインベン トリー中学生用（坂野ら,2007）: 学校ストレッサー, ストレ ス反応, ソーシャル・サポートの 3 尺度で構成されている。

2）レジリエンス尺度（石毛,2004）：意欲的活動性, 原因探求 性, 楽観性, 内的共有性の 4 下位尺度。

3）ライフスタイル：朝食摂取, 睡眠時間, 学習習慣など。

\section{3. 手続き}

2008 年 5 月 2011 年 2 月に年間 5 回, 計 15 回の質問紙調査 を実施した。配布回収は, 担任により学級単位で行われた。無記 名回答。ID として出席番号の記入を求めた。

\section{1. ストレス反応の 1 年間の変化}

\section{結 果}

ストレス反応得点の変化パターンについてクラスター分析 を行ったところ, 5 クラスターに分類された。各群の順位に 変化はなく, 全体の $45.2 \%$ (246人) は, 1 年を通じてスト レス反応得点が低いままであった。

\section{2. 学校ストレッサーとストレス反応の因果関係の検討}

各年度における 1 回目と 5 回目のストレス反応と学校スト レッサーの得点を用いて, 交差遅れ効果モデルと同時効果モ デルを作成し，因果の方向性の検討を行った（Fig. 1)。交差 遅れ効果モデルでは適合度が低くかった（ $\chi^{2}=134.21, \mathrm{p}<.01$, $\mathrm{CFI}=.84, \mathrm{RMSEA}=.35, \mathrm{AIC}=160.21)$ 。同時効果モデルの適合度 は充分であった（ $\left.\chi^{2}=0.37, \mathrm{CFI}=1.00, \mathrm{RMSEA}=.00, \mathrm{AIC}=26.37\right)$ 。
ストレス反応から学校ストレッサーへのパスが有意であった。 同時効果モデルを用いて, 年度当初にほとんどストレス反応 がみられない「健康群」と何らかの反応がみられる「症状あ り群」の 2 群で多母集団同時分析を行ったところ, 健康群で は，ストレス反応から学校ストレッサーへのパスのみが有意 であり, 症状あり群では双方向のパスが有意であった。モデ ルの適合度は充分であった $\left(\chi^{2}=2.08, \mathrm{CFI}=1.00, \mathrm{RMSEA}=.008\right.$, $\mathrm{AIC}=54.08)$ 。

\section{考 察}

入学から様々な生活の変化を体験しているにもかかわらず, 半数近くの生徒には自覚的なストレス反応がみられず健康な 様子がうかがわれた。さらにその傾向は 1 年間継続していた。

因果関係の検討では，ストレス反応が低い生徒で，経時的 にも同時的にも学校ストレッサーからストレス反応への影響 性が有意ではなかった。ストレス反応の低さが学校ストレッ サ一を低めている, 寸なわち，体調や気分がいい生徒は学業 や友人関係について肯定的に評価しているという様子が示さ れた。発表では, 健康な生徒たちのストレス反応を低めてい る要因についても検討を行うために, レジリエンスやライフ スタイルの影響を含めた分析結果を報告する。

\section{引用文献}

命婦恭子・工藤晋平・岩田昇（2010）中学生のストレス・プロ フィールにおける学校ストレスの縦断的変化 日本心理学会 第 74 回大会発表論文集

坂野雄二・岡安孝弘・嶋田洋徳（2007）PSI 小学生用・中学 生用・高校生用マニュアル. 実務教育出版

石毛みどり（2004）中学生におけるレジリエンスと無気力間 の関連. お茶の水女子大学人間文化論業, 6, 243-252.

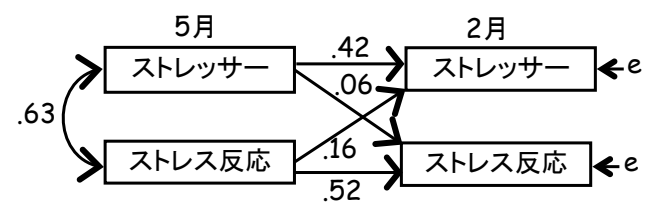

Fig. 1-1 学校ストレッサーとストレス反応の因果関係 (交差遅れ効果モデル)

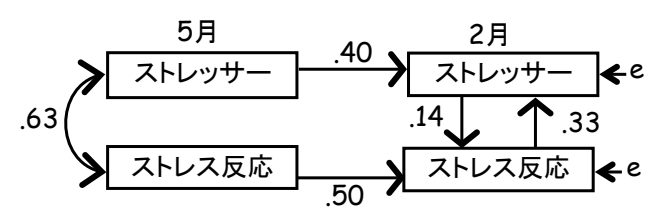

Fig. 1-2 学校ストレッサーとストレス反応の因果関係 (同時効果モデル) 